\title{
KEBIJAKAN DAN POLITIK HUKUM NASIONAL TENTANG AIR SUSU IBU DI INDONESIA PERSPEKTIF HUKUM ISLAM
}

\author{
Muklisin \\ Institut Agama Islam Yasni Bungo \\ Email: muklisinmukidi@gmail.com \\ Alaidin Koto \\ Universitas Islam Negeri Sultan Syarif Kasim Riau \\ Email: alaidinkoto@gmail.com \\ Silfia Hanani \\ Institut Agama Islam Negeri Bukittinggi \\ Emai: silfia_hanani@yahoo.com \\ Jumni Nelli \\ Universitas Islam Negeri Sultan Syarif Kasim Riau \\ Email: Jumni.nelli@uin-suska.ac.id
}

\begin{abstract}
Breastmilk (ASI) is the most important nutrient and the main food for babies that can not be replaced. The movement to provide exclusive breast milk is judged to be still less spoken and lacks support from many parties. The government has made regulations that guarantee the right of children to obtain breast milk as set out in Law No. 36 of 2009 on Health, and Government Regulation (PP) No. 33 of 2012 on Exclusive Breast Milk. This research aims to find out: a) How the government's policy regarding breastfeeding; b) How does breast milk (ASI) impact family life; C) How is the study of Islamic family law related to breastfeeding?. The type of this research is library research with a qualitative descriptive approach. Based on the results of the study can be concluded: 1) The Government's policy regarding breast milk (ASI) is the government made regulations that guarantee the right of the child to obtain breast milk (ASI) in Law No. 36 of 2009 on Health and Government Regulation (PP) No. 33 of 2012 on exclusive breast milk (ASI). 2) First, the impact of breast milk on family life is it can decrease the infant mortality rate. Second, it can increase the well being of the children. Third, it can improve the health status of mothers and babies. Fourth, it can save on household expenses tagged. Fifth, it can foster an example of love and humanity in parents and their children. 3) Review of Islamic law on breastfeeding rights for a mother. The fuqaha agreed that breastfeeding the child is an obligation for a mother because later it will be asked before Allah SWT.
\end{abstract}

Keywords : Breast Milk (ASI), Politicy, Islamic Law

Nur El-Islam, Volume 8, Nomor 1, April 2021 


\begin{abstract}
Abstrak
Air Susu Ibu (ASI) merupakan nutrisi terpenting bahkan merupakan makanan utama bagi bayi dimana tidak akan ada yang dapat menggantikan. Gerakan untuk memberikan ASI eksklusif dinilai masih kurang menggema dan minim dukungan dari banyak pihak. Padahal, pemerintah telah membuat peraturan yang menjamin hak anak untuk mendapatkan ASI seperti yang tertuang dalam Undang-Undang Nomor 36 Tahun 2009 Tentang Kesehatan, dan Peraturan Pemerintah (PP) Nomor 33 Tahun 2012 Tentang ASI Eksklusif. Penelitian ini bertujuan untuk mengetahui : a) Bagaimana kebijakan pemerintah terkait pemberian Air Susu Ibu (ASI); b) Bagaimana dampak Air Susu Ibu (ASI) pada kehidupan keluarga; C) Bagaimana kajian hukum keluarga Islam terkait pemberian Air Susu ibu (ASI) ?. Jenis penelitian ini adalah penelitian kepustakaan (library research) dengan pendekatan yang digunakan adalah bersifat deskriptif - kualitatif. Berdasarkan hasil penelitian dapat disimpulkan : 1) Kebijakan Pemerintah Terkait Air Susu Ibu (ASI) bahwa Pemerintah telah membuat peraturan yang menjamin hak anak untuk mendapatkan ASI seperti yang tertuang dalam Undang-Undang Nomor 36 Tahun 2009 tentang Kesehatan dan Peraturan Pemerintah (PP) Nomor 33 Tahun 2012 tentang ASI eksklusif. 2) Dampak Air Susu Ibu (ASI) pada kehidupan keluarga yaitu pertama, Air Susu Ibu (ASI) dapat menurunkan angka kematian bayi. Kedua, Air Susu Ibu (ASI) eksklusif dalam hal ini dapat mewujudkan kesejahteraan pada anak-anak. Ketiga, dapat meningkatkan status kesehatan pada ibu dan bayi. Kempat, dapat menghemat pengeluaran rumah tagga. Kelima, dapat menumbuhkan teladan cinta kasih dan kemanusiaan pada orangtua dan anaknya. 3) Tinjauan hukum Islam mengenai hak menyusui bagi seorang ibu. Dimana para fuqaha sepakat bahwa menyusui anak itu hukumnya wajib bagi seorang ibu, karena nanti hal itu akan ditanyakan di hadapan Allah SWT.
\end{abstract}

Kata Kunci : Air Susu Ibu (Asi), Kebijakan, Hukum Islam

\title{
A. Pendahuluan
}

Air Susu Ibu (ASI) merupakan nutrisi terpenting bahkan merupakan makanan utama bagi bayi dimana tidak akan ada yang dapat menggantikan. Berbagai penelitian telah mengkaji manfaat pemberian Air Susu Ibu (ASI) eksklusif dalam hal menurunkan mortalitas bayi. ASI mengandung komponen makro dan mikro sehingga membuat bayi mendapatkan pertumbuhan dan perkembangan yang optimal. World Health Organisation (WHO) telah merekomendasikan standar emas pemberian makanan pada bayi yaitu menyusui bayi secara eksklusif sejak lahir sampai dengan umur enam bulan, didahului dengan Inisiasi Menyusu Dini (IMD) segera setelah lahir, tetapi kenyataannya di Indonesia saat ini belum ada kesadaran 
para ibu untuk memberikan ASI eksklusif pada bayi. Hal ini dapat dilihat dari data Riset Kesehatan Dasar (Riskesdas) tahun 2018.

Riset Kesehatan Dasar (Riskesdas) tahun 2018 memperlihatkan bahwa hanya 58,2 \% proporsi ibu yang memberikan Inisiasi Menyusu Dini (IMD), sementara ibu yang tidak memberikan IMD sebesar 41,8 \%. ${ }^{1}$. Hal ini menunjukkan bahwa masih banyak ibu-ibu di Indonesia yang masih belum memberikan IMD. Hal ini mengindikasikan bahwa kesadaran masyarakat terhadap pentingnya IMD masih sangat kurang. Di Indonesia, rata-rata ibu memberikan ASI eksklusif hanya dua bulan. Pada saat yang bersamaan, pemberian susu formula meningkat tiga kali lipat. Tentu hal ini tidak sejalan dengan Undang Undang Dasar 1945 pada Pasal 28 B. $^{2}$

Saat ini, jumlah ibu yang memberikan ASI eksklusif kepada bayinya sampai berumur enam bulan masih rendah, yaitu kurang dari 2\% dari jumlah total ibu melahirkan. Hal tersebut lebih disebabkan oleh beberapa alasan, antara lain karena pengetahuan ibu tentang pentingnya ASI juga masih rendah, tata laksana rumah sakit yang salah, dan banyaknya ibu yang mempunyai pekerjaan di luar rumah. Beberapa rumah sakit memberikan susu formula pada bayi yang baru lahir sebelum ibunya mampu memproduksi ASI. Hal itu menyebabkan bayi tidak terbiasa mengisap ASI dari puting susu ibunya dan akhirnya

${ }^{1}$ Tri Windiarto, Al Huda Yusuf,dkk, Profil Anak Indonesia 2019, ( Jakarta : Diterbitkan oleh Kementerian Pemberdayaan Perempuan dan Perlindungan Anak (KPPPA), 2019), h. 66

${ }^{2}$ Dalam Undang-Undang Dasar Negara Republik Indonesia atau UUD 1945 pada perubahan amandemen yang kedua, pada Bab XA yang mengatur tentang Hak Asasi Manusia, pada pasal 28 B amandemen UUD 1945 kedua, ayat ke 2 menyebutkan bahwa “Setiap anak berhak atas kelangsungan hidup, tumbuh, dan berkembang serta berhak atas perlindungan dari kekerasan dan diskriminasi. Hal ini menurut penulis jika bayi tidak mendapatkan asupan ASI eksklusif yang cukup dan sesuai dengan anjuran dokter maka tidak sejalan dengan aturan UUD 1945 yang telah dibuat pada amandemen kedua pasal 28B. Apalagi menurut hukum islam anjuran untuk menyusui anak bahkan sampai 2 tahun baru disapihnya. Inilah kontradiksi antara hak bayi yang seharusnya mendapatkan layanan ASI, justru dalam kenyataannya belum optimal. 
tidak mau lagi mengkonsumsi ASI atau sering disebut dengan "bingung puting". ${ }^{3}$

Manfaat pemberian ASI makin dirasakan saat ASI diberikan secara eksklusif kepada bayi. Dari data Susenas tahun 2018 menunjukkan bahwa ibu di Indonesia cenderung memberikan air putih kepada bayinya selain ASI, yaitu sekitar 29,18 persen. Bayi usia 0-5 bulan yang diberi air lainnya (air tajin, madu, teh, air gula, dll) sekitar 8,30 persen. Data Susenas tahun 2018 menunjukkan bahwa 1 diantara 2 bayi usia 0-5 bulan diberi ASI eksklusif.

Sebaliknya di negara-negara maju seperti di Negara Amerika Serikat, di Jepang, di Inggris dan di Filipina, pemerintah sudah mengeluarkan kebijakan untuk memberikan ASI eksklusif kepada bayi, dan membuat kebijakan pelarangan memberikan susu formula dalam rangka mendukung ASI eksklusif. Di Negara Amerika Serikat bayi-bayi disana 60-70 \% mendapatkan ASI eksklusif. ${ }^{4}$ begitulah paradoks antara panduan dengan kesadaran. Sementara dari data di atas menunjukkan bahwa masih banyak ibu-ibu di Indonesia yang masih belum memberikan IMD. Sementara di Negara-negara maju seperti di

${ }^{3}$ Nurheti Yuliarti, Keajaiban ASI - Makanan Terbaik Untuk Kesehatan, Kecerdasan dan Kelincahan si Kecil, (Yogyakarta: Penerbit ANDI, 2010), hlm. 2. Istilah bingung puting dipakai untuk menggambarkan keadaan bayi yang mengalami nipple confusion karena diberi susu formula dalam botol bergantian dengan menyusu pada ibu. Mekanisme menyusu dan minum dari botol sangat berlainan. Untuk menyusui bayi memerlukan usaha yang "lebih" dari minum susu dari botol. Pada saat menyusu pada ibu, bayi mempergunakan otot-otot pipi, gusi, palatum durum (langit-langit) dan lidah untuk menarik dan mengurut puting serta areolanya untuk membentuk suatu "dot", kemudian ditekan oleh gusi atas dan bawah sehingga sinus laktiferus tertekan dan keluarlah ASI. Selanjutnya, dengan gerakan yang teratur ASI dihisap dan ditelan. Tidak demikian hal nya dengan bayi yang mendapat minuman dari botol, sebab dot mempunyai lubang sehingga tanpa berusaha keras bayi dapat menelan susu karena susu dapat terus keluar tanpa dihisap. Oleh sebab itulah kenapa bayi yang terbiasa dari botol "dot" akan sulit dan enggan menyusu dari ibunya. Ibu yang menggunakan botol dan dot biasanya beralasan bahwa produksi ASI- nya kurang, atau ibu sakit, misalnya payudaranya bengkak, puting susu nyeri atau lecet dan sebagainya.

${ }^{4}$ Nurheti Yuliarti, Keajaiban ASI- Makanan Terbaik Untuk Kesehatan, Kecerdasan dan Kelincahan Si Kecil, (Yogyakarta : Penerbit ANDI, 2010), h. 2 
Negara Amerika Serikat, justru berbanding terbalik dengan Negara Indonesia.

Hasil survei Demografi dan kesehatan Indonesia (SDKI) menunjukkan dari tahun ke tahun angka kematian bayi (AKB) mengalami penurunan. Dari 68 kematian per 1.000 kelahiran hidup pada tahun 1991, hingga 24 kematian per 1.000 kelahiran hidup pada tahun 2017. Namun, perkembangan terbaru dari beberapa daerah di tanah air menunjukkan AKB naik turun. Di Tangerang AKB justru meningkat setiap tahunnya. Pada tahun 2016 ada 102 kasus, pada tahun 2017 ada 144 kasus, dan pada tahun 2018 terdapat 247 kasus AKB. Demikian pula yang terjadi terhadap angka kematian bayi (AKB) naik juga terjadi di Kabupaten Malang, Jawa Timur. Pada tahun 2017, dimana angka kematian bayi (AKB) sebesar 1,61 \% naik menjadi 2,08 \% per 1000 kelahiran hidup di tahun 2018. ${ }^{5}$

Dalam upaya menurunkan angka kematian tersebut, berbagai upaya dilakukan, seperti imunisasi, pemberian ASI segera dan eksklusif. Upaya pencegahan terhadap penyakit infeksi dapat dilakukan apabila kondisi gizi dalam keadaan baik. Salah satu upaya agar gizi bayi tetap prima adalah dengan mendapat ASI sedini mungkin dan eksklusif. Air Susu Ibu (ASI) memegang peranan penting dalam menjaga kesehatan dan kelangsungan hidup bayi. Bahkan jiwa anak akan terselamatkan dengan memberikan asupan ASI dari ibunya.

Faktor yang mempengaruhi seorang ibu akan memberikan ASI eksklusif, seperti prilaku menyusui yang kurang dapat dukungan, pemberian makanan dan minuman sebelum ASI keluar, ibu kurang percaya diri kalau ASI-nya cukup untuk bayi, ibu kembali bekerja, dan yang paling dominan gencarnya promosi susu formula. Saat ini banyak sekali merek produk susu formula yang sangat gencar dalam mempromosikan produknya, baik media cetak dan media elektronik dengan memberikan hadiah yang menarik, sehingga para ibu banyak yang memilih produk susu formula dibandingkan dengan memberikan susu eksklusif kepada bayinya.

${ }^{5}$ Beritagar, Rapor Merah Angka Kematian Bayi di Indonesia. Diakses dari www. Beritagar.id pada hari Minggu, 14 April 2019 
Selain itu, sikap petugas kesehatan yang juga kurang mendukung, lemahnya perencanaan terpadu Peraturan Pemerintah Air Susu Ibu (PP ASI), dan sering terjadinya pergantian personil yang berdampak terhadap program PP ASI. Lagipula, lemahnya sanksi pelaksanaan Rumah Sakit Sayang Bayi (RSSB) berdampak hanya $25 \%$ yang masih RSSB, kurangnya integrasi dalam kurikulum tenaga kesehatan lintas sektor menyebabkan kendala dalam program PP ASI. 6 Pelaksanaan Peraturan Pemerintah No. 33 tahun 2012 tentang ASI eksklusif dinilai masih belum efektif sebagaimana diharapkan. Sejak diberlakukannya PP ini belum secara merata dipahami semua pihak. PP ini juga masih memiliki celah serta kelemahan, termasuk diantaranya celah dalam hal pemasaran produk pengganti ASI.

Gerakan untuk memberikan ASI secara eksklusif dinilai masih kurang menggema dan minim dukungan dari banyak pihak. Padahal, pemerintah telah membuat peraturan yang menjamin hak anak untukmendapatkan ASI seperti yang tertuang dalam Undang-Undang Nomor 36 Tahun 2009 Tentang Kesehatan, dan juga Peraturan Pemerintah (PP) Nomor 33 Tahun 2012 Tentang ASI Eksklusif. Menurut data Kesehatan Dasar (Riskesdas) tahun 2018 memperlihatkan bahwa hanya 58,2 \% proporsi ibu yang memberikan Inisiasi Menyusu Dini (IMD), sementara ibu yang tidak memberikan Inisiasi Menyusu Dini (IMD) sebesar 41,8. Padahal pemberian ASI tentu akan berdampak signifikan terhadap kualitas bangsa.

Hal ini memperlihatkan kegagalan pemerintah menjamin kesehatan dan kesejahteraan penduduk yang termaktub dalam Pasal 28 UUD 1945 khususnya Pasal 28 B Ayat 2 yang menyatakan “setiap anak berhak atas kelangsungan hidup, tumbuh dan berkembang serta berhak atas perlindungan dari kekerasan dan diskriminasi”. Disamping itu juga ada, UU No. 23 tahun 2002 tentang perlindungan anak yang menyebutkan tentang hak anak untuk hidup, tumbuh dan berkembang dengan baik masih jauh dari realisasinya.

${ }^{6}$ Departemen Kesehatan RI, Strategi nasional PP-ASI (edisi 2007). Diunduh dari : http ://www. Gizi.net/kebijakan-gizi/download/star-nas\%ofinal.com 
Arah kebijakan dan strategi pembangunan kesehatan nasional 2015-2019 merupakan bagian dari Rencana Pembangunan Jangka Panjang Bidang Kesehatan (RPJPK) 2005-2025, yang meningkatkan kesadaran, kemauan, kemampuan hidup sehat bagi setiap orang agar peningkatan derajat kesehatan masyarakat yang setinggi-tingginya dapat terwujud. Hal inilah politik hukum muncul dalam bentuk berupa kebijakan pemerintah terkait masalah pemberian ASI eksklusif. Dengan diwujudkan dalam Rencana Pembangunan Jangka Menengah Nasional (RPJMN) 2015-2019, dimana sasaran politik hukum yang ingin dicapai adalah meningkatkan derajat kesehatan dan status gizi masyarakat melalui upaya kesehatan dan pemberdayaan masyarakat. Pada tahun 2019, pemerintah menetapkan target penurunan Angka Kematian Bayi (AKB) menjadi 24 kematian per 1.000 kelahiran hidup. Dengan cara memberikan pertolongan kelahiran, Inisiasi Menyusu Dini (IMD), pemberian Air Susu Ibu (ASI) eklsklusif, imunisasi dan lainnya.

Di dalam ajaran Islam ada kewajiban menyusui kepada bayi yang tujuannya agar anaknya bisa berkembang dengan baik dan berkualitas. Dengan demikian, panduan Allah Swt tentang kewajiban memberikan ASI mendapatkan validasinya. Apalagi, ASI tidak hanya memenuhi asupan materi atau fisik semata. Lebih dari itu, melalui pemberian ASI terbina pula kontak bathin (psikis) antara si bayi dengan ibunya. Mari kita dalam firman Allah Swt berikut ini:

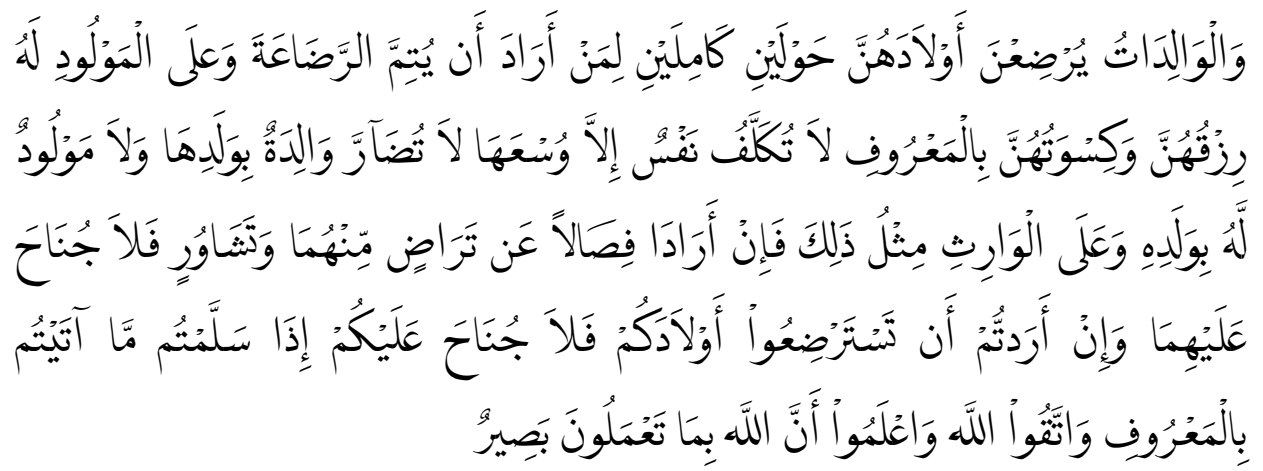


Artinya: "Para ibu hendaklah menyusukan anak-anaknya selama dua tahun penuh, Yaitu bagi yang ingin menyempurnakan penyusuan. Dan kewajiban ayah memberi Makan dan pakaian kepada Para ibu dengan cara ma'ruf. Seseorang tidak dibebani melainkan menurut kadar kesanggupannya. Janganlah seorang ibu menderita kesengsaraan karena anaknya dan seorang ayah karena anaknya, dan warispun berkewajiban demikian. Apabila keduanya ingin menyapih (sebelum dua tahun) dengan kerelaan keduanya dan permusyawaratan, Maka tidak ada dosa atas keduanya. dan jika kamu ingin anakmu disusukan oleh orang lain, Maka tidak ada dosa bagimu apabila kamu memberikan pembayaran menurut yang patut. Bertakwalah kamu kepada Allah dan ketahuilah bahwa Allah Maha melihat apa yang kamu kerjakan." (QS. Al-Baqarah [2] : 233) ${ }^{7}$

Ayat di atas mengingatkan kita untuk memperhatikan hak bayi terhadap air susu ibu-nya. Sang ibu tidak boleh menghindar dari kewajibannya memberikan ASI. Orang tua hanya lepas dari tuntutan jika bayinya telah mendapatkan haknya, baik dari ibu kandungnya, atau ibu susuannya. Jadi jelas di dalam ajaran Islam bahwa seorang ibu ada kewajiban untuk menyusui anaknya agar melahirkan anak-anak yang berkualitas baik secara fisik dan juga secara mental. Oleh karenanya pemerintah mengeluarkan Peraturan Pemerintah (PP) Nomor 33 Tahun 2012 yang mengatur tentang pemberian ASI eksklusif. Dengan dikeluarkannya kebijakan pemerintah tersebut itulah yang dimaksud dengan politik hukum.

Berdasarkan latar belakang tersebut di atas, penelitian ingin mengkaji kebijakan pemerintah dalam rangka pemenuhan hak anak terhadap ASI eksklusif apakah sudah memenuhi standar yang diinginkan. Sementara dalam agama Islam atau ajaran Al-Qur'an ada kewajiban memberikan ASI eksklusif kepada bayinya sehingga menciptakan generasi Islam yang berkualitas.

Pada penelitian ini pendekatan yang digunakan adalah menggunakan metode penelitian kualitatif dengan pendekatan deskriptif (deskriptif kualitatif). Dimana dalam pendekatan kualitatif ini sebagai prosedur penelitian yang menghasilkan data deskriptif berupa

${ }^{7}$ Al-Kalam, versi 1.0, (Bandung: Dipenogoro, 2009). 
kata-kata tertulis atau lisan dari orang-orang dan perilaku yang dapat diamati.

\section{B. Pembahasan}

1. Pengertian Air Susu Ibu (ASI)

Defenisi Air Susu Ibu (ASI) secara etimologi atau secara bahasa terdiri dari tiga kata. Dalam hal ini defenisi ketiga kata tersebut dapat dilihat dalam kamus besar bahasa Indonesia terbitan Balai Pustaka menjelaskan bahwa :

Air artinya cairan jernih tidak berwarna, tidak berasa, dan tidak berbau yang terdapat dan diperlukan dalam kehidupan manusia, hewan, dan tumbuhan yang secara kimiawi mengandung hidrogen dan oksigen. $^{8}$

Susu artinya organ tubuh yang terletak di bagian dada, atau organ tubuh yang terletak di dada wanita yang dapat menghasilkan makanan untuk bayi, berupa cairan. ${ }^{9}$ Sedangkan Ibu artinya wanita yang telah melahirkan seseorang atau anak. ${ }^{10}$

Jadi Air Susu Ibu (ASI) adalah makanan pertama yang paling baik bagi awal kehidupan seorang bayi. ASI mengandung semua zat gizi yang dibutuhkan dengan jumlah kandungan yang tepat dan menyediakan antibodi atau zat kekebalan untuk membantu melawan infeksi. ${ }^{11}$

Air Susu Ibu (ASI) adalah cairan hasil sekresi kalenjer payudara ibu. Sedangkan Air Susu Ibu Eksklusif adalah ASI yang diberikan pada bayi sejak dilahirkan selama 6 bulan, tanpa menambahkan dan mengganti dengan makanan atau minuman lain. Pemberian Air Susu Ibu (ASI) secara eksklusif kehidupan bayi dan memberi dampak yang baik bagi kesehatan ibu.

ASI juga mengadung hormon dan berbagai faktor pemacu pertumbuhan anak. Kadar asam lemak yang tinggi di dalam Air Susu

${ }^{8}$ Pusat Bahasa Departemen Pendidikan Nasional, Kamus Besar Bahasa Indonesia, (Jakarta, Balai Pustaka, 2005), h. 15

${ }^{9}$ Ibid, h. 1111

10 Ibid, h. 416

11 Sara Lewis, Makanan Pertamaku Panduan Para Ibu Untuk Menyapih Dan Mengenalkan Makanan Padat, (Jakarta : Erlangga, 2000), h. 10 
Ibu (ASI) juga melindungi bayi dari kemungkinan alergi (terutama yang memiliki riwayat kurang toleran terhadap makanan atau alergi, seperti asma atau eksema).

\section{Keunggulan Air Susu Ibu (ASI)}

Tidak diragukan lagi mengenai keunggulan ASI yang merupakan makanan terbaik bagi bayi. Hampir semua kalangan, termasuk dunia kedokteran ikut menganjurkan supaya ibu lebih memilih ASI sebagai makanan utama bayi dibandingkan dengan susu formula. Susu formula yang diproduksi melalui pabrik yang bahan bakunya berasal dari susu hewan sapi atau sejenisnya kurang bagus untuk pertumbuhan bayi diawal-awal kelahirannya. Sungguh disayangkan saat ini masih banyak ibu-ibu yang enggan menyusui bayinya, hanya karena alasan sibuk bekerja, untuk menjaga penampilan dan alasan lainnya.

Jikalau dibandingkan dengan susu formula maka ASI banyak memiliki keunggulan yang sangat banyak diantaranya yaitu :

1. Diproduksi sesuai dengan kebutuhan.

2. Lebih mudah dicerna.

3. Sangat aman untuk bayi.

4. Baik untuk sistem pencernaan bayi.

5. Mendukung pertumbuhan otak.

6. Tidak menyebabkan obesitas (kegemukan).

7. Mencegah alergi.

8. Mencegah infeksi.

9. Mengoptimalkan perkembangan mulut bayi. ${ }^{12}$

Air susu ibu (ASI) merupakan sumber makanan utama yang sangat banyak sekali keunggulannya dibandingkan susu formula. Proses pemberian ASI bukan hanya berguna bagi bayi melainkan juga berguna bagi sang ibu. Dimana anak akan mendapatkan imun (kekebalan tubuh) dari sang ibu secara langsung dan ibu juga akan menjadi sehat karena bisa memberikan asupan gizi dan zat imun

12 Avie Andriyani, Panduan Kesehatan Wanita (haid,hamil,melahirkan,nifas,dan menyusui), (Yogyakarta: As-Salam Publishing Group, 2013), h. 102 
kepada anak bayinya. Dalam hal ini jelas bahwa ASI memiliki keunggulan yang jauh dibandingkan dengan susu formula yang dijual di pasaran.

\section{Definisi Kebijakan Publik}

Kebijakan publik mempunyai banyak pemahaman teoretis. Harold Laswell dan Abraham Kaplan ${ }^{13}$ mendefinisikannya sebagai suatu program yang diproyeksikan dengan tujuan-tujuan tertentu nilainilai tertentu, dan praktik-praktik tertentu (a projected program of goals, values, and practices). David Easton ${ }^{14}$ mendefinisikannya sebagai akibat dari aktivitas pemerintah (the impact of government activity). James Anderson ${ }^{15}$ mendefinisikannya sebagai a relative stable, purposive course of action followed by an actor or set of actors in dealing with a problem or matter of concern.

James Lester dan Robert Steward ${ }^{16}$ mendefinisikannya sebagai $a$ process or a series or pattern of governmental activities or decissions that are design to remedy some public problem, either real or imagined. Austin Steven A. Peterson ${ }^{17}$ mendefinisikannya sebagai government action to address some problem. B. G. Peters ${ }^{18}$ mendefinisikannya sebagai the sum of government activities, wether acting directly or through agents, as it has an influence on the lives of citizens.

Dari pemahaman teoretis tersebut, kita dapat merumuskan definisi sebagai berikut : "kebijakan publik adalah keputusan yang dibuat oleh Negara, khususnya Pemerintah, sebagai strategi untuk merealisasikan tujuan dari Negara yang bersangkutan. Kebijakan publik adalah strategi untuk mengantar masyarakat pada masa awal, memasuki masyarakat pada masa transisi, untuk menuju kepada masyarakat yang dicita-citakan.”

${ }^{13}$ Lasweel dan Kaplan Power and Society (1970), h. 71

${ }^{14}$ Easton A System Analysis of Political Life (1965), h. 212

${ }^{15}$ Anderson Public Policy Making (2000), h. 4

${ }^{16}$ Lester dan Steward Public Policy: an Evolutionary Approach (2000), h. 18

${ }^{17}$ Peterson "Public Policy" dalam Jack Rabin (2003) Encyclopedia of Public Administration and Public Policy (2003), h. 1030

${ }^{18}$ Peters American Public Policy (1993), h. 4 


\section{Definisi Politik Hukum}

Politik hukum adalah legal policy atau garis (kebijakan) resmi tentang hukum yang akan diberlakukan baik dengan pembuatan hukum baru maupun dengan penggantian hukum lama, dalam rangka mencapai tujuan negara. Dengan demikian, politik hukum merupakan pilihan tentang hukum-hukum yang akan diberlakukan sekaligus pilihan tentang hukum-hukum yang akan dicabut atau tidak diberlakukan yang kesemuanya dimaksudkan untuk mencapai tujuan negara seperti yang tercantum di dalam Pembukaan UUD 1945. ${ }^{19}$

Padmo Wahjono mengatakan bahwa politik hukum adalah kebijakan dasar yang menentukan arah, bentuk, maupun isi hukum yang akan dibentuk. ${ }^{20}$ Padmo Wahjono memperjelas definisi tersebut dengan mengatakan bahwa politik hukum adalah kebijakan penyelenggara negara tentang apa yang dijadikan kriteria untuk menghukumkan sesuatu yang di dalamnya mencakup pembentukan, penerapan, dan penegakan hukum. ${ }^{21}$ Teuku Mohammad Radhie mendefinisikan politik hukum sebagai suatu persyaratan kehendak penguasa negara mengenai hukum yang berlaku di wilayahnya dan mengenai arah perkembangan hukum yang dibangun. ${ }^{22}$

Mantan ketua perancang Kitab Undang-Undang Hukum Pidana (KUHP) Soedarto mengemukakan bahwa politik hukum adalah kebijakan negara melalui badan-badan negara yang berwenang untuk menetapkan peraturan-peraturan yang dikehendaki yang diperkirakan akan dipergunakan untuk mengekspresikan apa yang terkandung dalam masyarakat dan untuk mencapai apa yang dicita-citakan. ${ }^{23}$ Pada tahun 1986, Soedarto mengemukakan kembali bahwa politik hukum

${ }^{19}$ Mahfud MD, Politik Hukum di Indonesia, (Depok : Rajawali Pres, 2019), h. 1

${ }^{20}$ Padmo Wahjono, Indonesia Negara Berdasarkan Atas Hukum, (Jakarta: Ghalia Indonesia, 1986), Cet. II, h. 160

${ }^{21}$ Padmo Wahjono, "Menyelisik Proses Terbentuknya Peraturan Perundangundangan”, dalam majalah Forum Keadilan, No. 29, April 1991, h. 65

${ }^{22}$ Teuku Mohammad Radhie, "Pembaruan dan Politik Hukum dalam Rangka Pembangunan Nasional”, dalam majalah Prisma No. 6 Tahun II, Desember 1973, h. 3

${ }^{23}$ Soedarto, Hukum Pidana dan Perkembangan Masyarakat, Kajian Terhadap Hukum Pidana, (Bandung: Sinar Baru, 1983), h. 20 
merupakan upaya untuk mewujudkan peraturan-peraturan yang baik sesuai dengan keadaan dan situasi pada suatu waktu. ${ }^{24}$

\section{Kedudukan Politik Hukum}

Politik hukum nasional harus dapat mendorong dan mengisi semua unsur di dalam sistem hukum nasional agar bekerja sesuai dengan cita-cita bangsa, tujuan negara, cita hukum, dan kaidah penentuan hukum di negara Republik Indonesia sebagaimana terkandung dalam Pembukaan UUD 1945. ${ }^{25}$

Mahfud MD mengemukakan beberapa ahli yang pernah mengemukakan definisi politik hukum sebagai berikut: ${ }^{26}$

a. Teuku Muhammad Radhi, mendefinisikan politik hukum sebagai suatu pernyataan kehendak penguasa negara mengenai hukum yang berlaku di wilayahnya dan mengenai arah perkembangan hukum yang dibangun.

b. Padmo Wahyono, mengemukakan bahwa politik hukum adalah kebijakan dasar yang menentukan arah, bentuk, maupun isi dari hukum yang akan dibentuk.

c. Soedarto, mengemukakan bahwa politik hukum adalah kebijakan negara melalui badan-badan negara yang berwenang untuk menetapkan peraturan-peraturan yang dikehendaki dan diperkirakan akan digunakan untuk mengekspresikan apa yang terkandung dalam masyarakat dan untuk mencapai apa yang dicita-citakan.

d. Satjipto Rahardjo, mengemukakan bahwa politik hukum adalah aktivitas memilih cara yang hendak dipakai untuk menciptakan suatu tujuan sosial dan hukum tertentu dalam masyarakat. Dalam hal ini berkaitan dengan pertanyaan: 1) tujuan apa yang hendak dicapai melalui sistem yang ada; 2) cara apa dan yang mana yang dirasa paling baik untuk dipakai dalam mencapai tujuan tersebut;

\footnotetext{
${ }^{24}$ Soedarto, Hukum dan Hukum Pidana, (Bandung: Alumni, 1986), h. 151

${ }^{25}$ Mahfud MD, Membangun Politik Hukum, Menegakkan Konstitusi, (Jakarta: Pustaka LP3ES, 2006), h. 13

${ }^{26}$ Mahfud MD, Membangun Politik Hukum, Menegakkan Konstitusi, (Jakarta: Pustaka LP3ES, 2006), h. 13-16
} 
3) kapan waktunya dan melalui cara bagaimana hukum itu perlu diubah; 4) dapatkah suatu pola yang baku dan mapan dirumuskan untuk membantu dalam memutuskan proses pemilihan tujuan serta cara-cara untuk mencapai tujuan tersebut dengan baik.

e. Abdul Hakim Garuda Nusantara, mengemukakan bahwa politik hukum adalah legal policy atau kebijakan hukum yang hendak diterapkan atau dilaksanakan secara nasional oleh suatu pemerintahan negara tertentu yang meliputi: 1) pelaksanaan secara konsisten ketentuan hukum yang telah ada; 2) pembangunan hukum yang berintikan pembaruan atas hukum yang telah ada dan pembuatan hukum-hukum yang baru; 3) penegasan fungsi lembaga penegak hukum serta pembinaan para anggotanya; dan 4) peningkatan kesadaran hukum masyarakat menurut persepsi elite pengambil kebijakan.

Atas dasar pemahaman tersebut dapat dikatakan bahwa politik hukum merupakan aktivitas yang menentukan pola atau cara membentuk hukum, mengawasi bekerjanya hukum, dan memperbarui hukum untuk mencapai tujuan negara. Pengelolaan keuangan daerah dalam tinjauan politik hukum diarahkan untuk terciptanya tata kelola yang baik atau good financial governance yang mengharuskan berfungsinya seluruh unsur dalam sistem pengelolaan keuangan daerah. Kebijakan pengelolaan keuangan daerah harus diletakkan pada pelaksanaan semua aturan hukum keuangan daerah, serta pelaksanaan visi,misi, dan program pembangunan pemerintah daerah baik Rencana Kerja Pembangunan Jangka Pendek Daerah (RKPD), Rencana Kerja Pembangunan Jangka Menengah Daerah (RPJMD), dan Rencana Kerja Pembangunan Jangka Panjang Daerah (RPJPD).

\section{Hasil Penelitian dan Pembahasan}

A. Kebijakan Pemerintah Terkait Pemberian Air Susu Ibu (ASI)

1. Kebijakan Pemberian ASI Eksklusif Menurut Undang-Undang Nomor 36 Tahun 2009 Tentang Kesehatan.

Pasal 128 ayat (1), (2), dan (3) Undang-undang Nomor 36 Tahun 2009 tentang Kesehatan, dirumuskan bahwa : 
(1) Setiap bayi berhak mendapatkan air susu ibu eksklusif sejak dilahirkan selama 6 (enam) bulan, kecuali atas indikasi medis.

(2) Selama pemberian air susu ibu, pihak keluarga, pemerintah, pemerintah daerah, dan masyarakat harus mendukung ibu bayi secara penuh dengan penyediaan waktu dan fasilitas khusus.

(3) Penyediaan fasilitas khusus sebagaimana dimaksud pada ayat (2) diadakan di tempat kerja dan tempat sarana umum.

Berdasarkan ketentuan di atas, dapat ditarik kesimpulan bahwa bayi berhak mendapatkan ASI secara eksklusif sejak lahir sampai berusia 6 (enam) bulan, dan ibu mempunyai kewajiban untuk menyusui bayinya secara eksklusif kecuali atas indikasi medis. Selama proses pemberian ASI eksklusif, ibu bayi mempunyai hak untuk didukung secara penuh, dalam hal ini keluarga, pemerintah, pemerintah daerah serta masyarakat wajib untuk mendukung proses pemberian ASI eksklusif ini.

Dalam Undang-undang Nomor 13 Tahun 2003 Tentang Ketenagakerjaan, pada Pasal 82 ayat (1) disebutkan bahwa : "pekerja/buruh perempuan berhak memperoleh istirahat selama 1,5 (satu setengah) bulan sebelum saatnya melahirkan anak dan 1,5 (satu setengah) bulan sesudah melahirkan menurut perhitungan dokter kandungan atau bidan”. Sehingga pada saat bayi berumur 1,5 bulan, seorang ibu pekerja sudah harus meninggalkan bayinya untuk kembali bekerja.

Dukungan perusahaan bagi keberhasilan program ASI eksklusif sebenarnya bisa diberikan melalui pemberian cuti melahirkan kepada setiap pekerja perempuan. Di Indonesia, setiap perusahaan seharusnya mengikuti ketentuan Undang-undang Nomor 13 tahun 2003 tentang ketenagakerjaan dengan memberikan hak cuti selama 3 bulan kepada karyawan yang melahirkan. Pada kenyataannya banyak perusahaan yang hanya memberikan cuti kurang dari 3 bulan.

Pasal 129 ayat (1) dan (2) Undang-undang Nomor 36 Tahun 2009 tentang kesehatan, dirumuskan bahwa :

(1) Pemerintah bertanggung jawab menetapkan kebijakan dalam rangka menjamin hak bayi untuk mendapatkan air susu ibu secara eksklusif. 
(2) Ketentuan lebih lanjut sebagaimana dimaksud pada ayat (1) diatur dengan peraturan pemerintah.

Melihat ketentuan di atas, pemerintah harus menetapkan kebijakan dalam rangka menjamin terpenuhinya hak bayi untuk mendapatkan ASI secara eksklusif. Pada tanggal 1 Maret 2012 yang lalu, pemerintah telah mengeluarkan Peraturan Pemerintah Nomor 33 Tahun 2012 tentang Pemberian Air Susu Ibu Eksklusif yang ditanda tangani oleh presiden Susilo Bambang Yudhoyono.

Pasal 200 dan Pasal 201 ayat (1) dan (2) Undang-undang Nomor 36 tahun 2009 tentang kesehatan, dirumuskan bahwa :

Pasal 200

Setiap orang dengan sengaja menghalangi program pemberian air susu ibu eksklusif sebagaimana dimaksud dalam Pasal 128 ayat (2) dipidana penjara paling lama 1 (satu) tahun dan denda paling banyak Rp. 100.000.000,00 (seratus juta rupiah)

Pasal 201

(1) Dalam hal tindak pidana sebagaimana dimaksud dalam Pasal 190 ayat (1), Pasal 191, Pasal 192, Pasal 196, Pasal 197, Pasal 198, Pasal 199, dan Pasal 200 dilakukan oleh korporasi, selain pidana penjara dan denda terhadap pengurusnya, pidana yang dapat dijatuhkan terhadap korporasi berupa pidana denda dengan pemberatan 3 (tiga) kali dari pidana denda sebagaimana dimaksud dalam Pasal 190 ayat (1), Pasal 191, Pasal 192, Pasal 196, Pasal 197, Pasal 198, Pasal 199, dan Pasal 200.

(2) Selain pidana denda sebagaimana dimaksud pada ayat (1), korporasi dapat dijatuhi pidana tambahan berupa:

a. Pencabutan izin usaha; dan/atau

b. Pencabutan status badan hukum.

Berdasarkan ketentuan di atas, dapat kita simpulkan bahwa apabila ada seseorang yang dengan sengaja menghalangi proses pemberian ASI eksklusif akan dikenai sanksi pidana penjara paling lama 1 (satu) tahun dan denda paling banyak Rp. 100.000.000,(seratus juta rupiah). Apabila pelanggaran tersebut dilakukan oleh korporasi, maka dendanya yang dikenakan 3 (tiga) kali lipat dari denda perorangan, serta akan dikenai sanksi tambahan berupa pencabutan 
izin usaha atau pencabutan status badan hukum. Hal ini menjadi bukti bahwa jaminan terhadap hak bayi dan ibu sedemikian didukung oleh pemerintah, sehingga apabila ada pihak yang tidak mentaati aturan tersebut akan dikenakan sanksi. Penjatuhan sanksi dapat kepada person (seseorang yang menghalangi ibu untuk menyusui bayinya), maupun kepada lembaga (dalam hal ini dapat dijatuhkan pada pemerintah, pengusaha, maupun perusahaan swasta yang melanggar ketentuan di atas). Sayang sekali sampai sekarang sanksi yang berlaku belum bisa ditegakkan sebagaimana mestinya.

\section{Peran Pemerintah Daerah dan DPRD.}

Terkait dengan kebijakan oleh pemerintah sebenarnya masalah pemberian Air Susu Ibu (ASI) eksklusif seharusnya sudah menjadi perhatian khusus. Mengapa demikian?. Hal itulah yang akan penulis uraikan bagaimana seharusnya pemerintah daerah dan DPRD mengambil posisi dalam kebijakan Air Susu Ibu (ASI) ini. Ketika lembaga pemerintah atau eksekutif tidak mampu bersinergi dengan DPRD dalam hal ini legislative maka sebuah kebijakan akan berjalan pincang dan tidak akan optimal. Sebut saja Perda (Peraturan daerah) yang sudah dibuat oleh legislatinf/DPRD ketika tidak dijalankan dengan baik oleh pemerintah dalam hal ini eksekutif maka akan mandul dikemudian hari.

Kalau kita bicara tentang kebijakan ASI eksklusif di Indonesia mengalami proses yang cukup panjang, tercatat sampai saat ini sudah terdapat 5 kali peraturan yang dikeluarkan terkait dengan pemberian ASI eksklusif di Negara Indonesia ini. Yaitu pertama Pemerintah mengeluarkan Permenkes RI No. 240/MENKES/PER/V/1985 tentang Pengganti ASI, kemudian keluar lagi Kepmenkes RI No. 237/Menkes/SK/IV/1997 tentang pemasaran pengganti ASI, kemudian keluar lagi Peraturan Pemerintah No. 69 tahun 1999 tentang label dan iklan pangan, kemudian keluar lagi peraturan Kepmenkes RI No. 450/Menkes/SK/IV/2004 tentang pemberian ASI secara eksklusif pada bayi di Indonesia. Dan yang terbaru yaitu keluarnya Peraturan Pemerintah Nomor 33 tahun 2012 tentang Pemberian ASI eksklusif. 
Dari beberapa perubahan peraturan ataupun kebijakan terkait pemberian ASI seperti yang saya sebutkan di atas, bahwa perubahanperubahan tersebut bukan karena sebab. Melainkan pemerintah sebenarnya menginginkan varian baru terkait peraturan kebijakan pemberian ASI eksklusif yang tepat. Namun, hal tersebut menurut hemat penulis belum sampai pada tataran peraturan di tingkat bawah, seperti di daerah-daerah kabupaten kota yang ada di Indonesia.

Seyogyanya, peraturan pemerintah yang sudah dibuat atau dikeluarkan juga disosialisasikan bahkan kalau perlu dibuat juga aturan mengenai pemberian ASI eksklusif sampai tataran peraturan di daerah masing-masing. Dalam hal ini peran pemerintah daerah baik Gubernur ataupun Bupati menjalin kerjasama yang baik dengan Dewan DPRD untuk membuat kebijakan berupa Perda (peraturan daerah) terkait masalah pemberian Air Susu Ibu (ASI) eksklusif pada ibu kepada bayinya di awal-awal baru melahirkan bayinya. Sehingga dalam hal ini program pemerintah akan sampai pada tataran di daerah masing-masing.

\section{B. Dampak Air Susu Ibu (ASI) Pada Kehidupan Keluarga}

a. Air Susu Ibu (ASI) Menurunkan Angka Kematian Bayi.

Pemberian Air Susu Ibu (ASI) pada bayi mempunyai banyak manfaat. Pemberian ASI dapat menurunkan angka kematian, menurunkan angka kesakitan bayi, mengoptimalkan pertumbuhan, membantu perkembangan kecerdasan, dan memberikan sejumlah manfaat bagi ibu seperti membantu memperpanjang jarak kehamilan, dan terhindar dari kanker payudara dan ovarium, serta dapat meningkatkan ikatan ibu dan bayinya.

Manfaat pemberian Air Susu Ibu (ASI) eksklusif dalam hal menurunkan mortalitas bayi sangat besar sekali perannya. ASI mengandung komponen makro dan mikro sehingga membuat bayi mendapatkan pertumbuhan dan perkembangan yang optimal. World Health Organisation (WHO) telah merekomendasikan standar emas pemberian makanan pada bayi yaitu menyusui bayi secara eksklusif sejak lahir sampai dengan umur 6 bulan, didahului dengan Inisiasi Menyusu Dini (IMD) segera setelah lahir, tetapi kenyataannya di 
Indonesia saat ini belum ada kesadaran para ibu untuk memberikan ASI ekskulsif pada bayi. Hal ini dapat dilihat dari data Riset Kesehatan Dasar (Riskesdas) tahun 2018.

Hasil survei demografi dan kesehatan Indonesia (SDKI) menunjukkan dari tahun ke tahun AKB mengalami penurunan. Dari 68 kematian per 1.000 kelahiran hidup pada tahun 1991, hingga 24 kematian per 1.000 kelahiran hidup pada tahun 2017. Namun, perkembangan terbaru dari beberapa daerah di tanah air menunjukkan AKB naik turun. Di Tangerang AKB justru meningkat setiap tahunnya. Pada tahun 2016 ada 102 kasus, pada tahun 2017 ada 144 kasus, dan pada tahun 2018 terdapat 247 kasus AKB. Demikian pula yang terjadi terhadap angka kematian bayi (AKB) naik juga terjadi di Kabupaten Malang, Jawa Timur. Pada tahun 2017, dimana angka kematian bayi (AKB) sebesar 1,61 \% naik menjadi 2,08\% per 1000 kelahiran hidup di tahun 2018. ${ }^{27}$

Arah kebijakan dan strategi pembangunan kesehatan nasional 2015-2019 merupakan bagian dari Rencana Pembangunan Jangka Panjang Bidang Kesehatan (RPJPK) 2005-2025, yang meningkatkan kesadaran, kemauan, kemampuan hidup sehat bagi setiap orang agar peningkatan derajat kesehatan masyarakat yang setinggi-tingginya dapat terwujud.

\section{b. ASI Eksklusif Mewujudkan Kesejahteraan Anak}

Sudah dipahami bersama, periode emas pertumbuhan anak adalah dimasa 1000 hari pertama kehidupan yang dihitung sejak awal pertumbuhan. Segala bentuk pertumbuhan jasmani dan perkembangan anak mencapai puncak maksimal di masa ini. Atau disebut juga dengan usia golden age (usia emas) yaitu dari 0-5 tahun. Otak mengalami evolusi terbesarnya, demikian halnya pemahaman emosional anak. Banyak sikap dan kemampuan bahasa terbentuk di masa ini.

${ }^{27}$ Beritagar, Rapor Merah Angka Kematian Bayi di Indonesia. Diakses dari www. Beritagar.id pada hari Minggu, 14 April 2019 


\section{c. Meningkatkan Status Kesehatan Ibu dan Bayi}

Salah satu faktor mudah yang sering dilupakan bahkan diabaikan oleh orangtua terutama ibu-ibu adalah Air Susu Ibu (ASI). ASI adalah karunia Tuhan yang memang disediakan dan dibutuhkan oleh anak yang baru lahir. Ibu-ibu yang baru saja melahirkan bayinya tidak perlu susah-susah mencari nutrisi yang paling bagus buat anak kesayangannya karena sudah disediakan Tuhan. Bahkan para dokter dan ahli sangat menganjurkan agar cairan pertama yang berwarna kekuning-kuningan yang keluar dari puting payudara ibu yang baru melahirkan langsung diberikan kepada anaknya.

\section{d. Menghemat Pengeluaran Rumah Tangga.}

Banyak tindakan yang relatif murah dan mudah diterapkan untuk meningkatkan kesehatan dan kelangsungan hidup anak, terutama bayi baru lahir yaitu memberikan ASI secara eksklusif. Ibu dapat menghemat banyak biaya karena tidak perlu membeli botol susu, dot, dan susu formula yang harganya bisa sangat mahal. Apalagi bayi yang mendapat ASI insyaAllah akan lebih jarang sakit sehingga hal ini tentunya akan menekan pengeluaran keluarga untuk biaya pengobatan.

\section{e. Menumbuhkan Teladan Cinta Kasih dan Kemanusiaan}

Janin adalah mahluk ajaib yang sangat peka terhadap rangsangan. Sejak hari pertama janin dinyatakan ada dalam rahim hingga kurun waktu sembilan bulan, janin tidak pernah berhenti hidup dan berkembang. Setelah sang ibu melahirkan, dan ibu langsung memberikan ASI eksklusif maka ketika secara langsung jalinan cinta kasih antara ibu dan bayinya akan terasa. Hubungan antara ibu dan bayinya akan lebih erat dan akrab. Pelukan yang diberikan oleh sang ibu kepada bayinya menjadi kehangatan tersendiri bagi bayi dan ibunya. Karena sejatinya, seorang bayi ketika baru lahir yang dicari adalah ASI dari ibunya langsung bukan dari susu formula atau susu botol. 


\section{Kajian Hukum Keluarga Islam Terkait Pemberian ASI}

Dalam Surat Al-Baqarah ayat 233 dijelaskan secara tegas tentang perintah menyusukan anaknya selama dua tahun penuh. Dalam kajian ilmu tafsir Al-Mishbah dijelaskan bahwa dengan menggunakan redaksi berita, ayat ini memerintahkan dengan sangat kukuh kepada para ibu agar menyusukan anak-anaknya. Kata al-waalidaat dalam penggunaan al-Qur'an berbeda dengan kata ummahaat yang merupakan bentuk jamak dari kata umm. Kata ummahaat digunakan untuk menunjuk kepada para ibu kandung, sedangkan kata al-waalidaat maknanya adalah para ibu, baik ibu kandung maupun bukan. ${ }^{28}$ Ini berarti bahwa al-Qur'an sejak dini telah menggariskan bahwa Air Susu Ibu (ASI), baik ibu kandung maupun bukan, adalah makanan terbaik buat bayi hingga usia dua tahun. Namun demikian, tentunya air susu ibu kandung lebih baik dari selainnya. Dengan menyusu pada ibu kandung, anak akan merasa lebih tenteram, sebab menurut penelitian ilmuan, ketika itu bayi mendengar suara detak jantung ibu yang telah dikenalnya secara khusus sejak dalam perut. Detak jantung itu berbeda antara seorang wanita dengan wanita yang lain. Sejak kelahiran hingga dua tahun penuh, para ibu diperintahkan untuk menyusukan anak-anaknya.

\section{Kesimpulan}

Berdasarkan permasalahan yang telah diuraikan dalam penelitian ini, maka dapat peneliti simpulkan sebagai berikut :

1. Kebijakan Pemerintah Terkait Air Susu Ibu (ASI) bahwa dalam Pasal 128 ayat (1), (2), dan (3) Undang-undang Nomor 36 Tahun 2009 tentang Kesehatan, dirumuskan bahwa : Pertama, Setiap bayi berhak mendapatkan air susu ibu eksklusif sejak dilahirkan selama 6 (enam) bulan, kecuali atas indikasi medis. Kedua, Selama pemberian air susu ibu, pihak keluarga, pemerintah, pemerintah daerah, dan masyarakat harus mendukung ibu bayi secara penuh dengan penyediaan waktu dan fasilitas khusus. Ketiga, Penyediaan fasilitas khusus sebagaimana dimaksud pada ayat (2) diadakan di

${ }^{28}$ M. Quraish Shihab, Tafsir Al-Mishbah Pesan, Kesan dan Keserasian Al-Qur'an, (Jakarta ; Lentera Hati, 2002), h. 503 
tempat kerja dan tempat sarana umum. Gerakan untuk memberikan ASI secara eksklusif dinilai masih kurang menggema dan minim dukungan dari banyak pihak. Padahal, pemerintah telah membuat peraturan yang menjamin hak anak untuk mendapatkan ASI seperti yang tertuang dalam Undang-undang Nomor 36 Tahun 2009 tentang Kesehatan terkait Pasal-Pasal pemberian ASI eksklusif, dan juga Peraturan Pemerintah (PP) Nomor 33 Tahun 2012 tentang ASI eksklusif.

2. Dampak Air Susu Ibu (ASI) pada kehidupan keluarga ada 5 hal yaitu pertama, Air Susu Ibu (ASI) dapat menurunkan angka kematian bayi. Bayi yang mendapatkan ASI akan lebih sehat dan terhindar dari berbagai penyakit infeksi. Hal inilah yang dapat menurunkan angka kematian bayi. Kedua, Air Susu Ibu (ASI) eksklusif dalam hal ini dapat mewujudkan kesejahteraan pada anak-anak. Ketiga, dapat meningkatkan status kesehatan pada ibu dan bayi. Ibu yang memberikan ASI eksklusifnya kepada bayi akan menjadi sehat baik secara jasmani dan rohani. Kempat, dapat menghemat pengeluaran rumah tangga. Dimana dengan memberikan ASI eksklusif kepada bayinya maka orangtua tidak perlu lagi memberikan susu formula, ibu bisa menghemat banyak biaya karena tidak perlu membeli botol susu, dot, dan susu formula yang harganya bisa sangat mahal. Kelima, dapat menumbuhkan teladan cinta kasih dan kemanusiaan pada orangtua dan anaknya.

3. Tinjauan hukum Islam mengenai hak menyusui bagi seorang ibu. Dimana para fuqaha sepakat bahwa menyusui anak itu hukumnya wajib bagi seorang ibu, karena nanti hal itu akan ditanyakan di hadapan Allah SWT, baik wanita tersebut masih menjadi istri ayah dari bayi maupun sudah dicerai dan sudah selesai iddahnya. Sementara itu Ulama Syafi'iyyah mewajibkan bagi seorang ibu untuk menyusui anaknya pada awal kelahiran anak karena umumnya seorang bayi tidak mampu hidup tanpa susu tersebut, dan susu tersebut tidak bisa digantikan dengan yang lainnya. 


\section{Daftar Pustaka}

Abdullah, Abdul Hakim, Keutamaan Air Susu Ibu, Jakarta: Fikahati Aneska, 1993.

Aini, Rafiah, "Studi Kritis Pemikiran Yusuf Qardawi Tentang Bank ASI (Air Susu Ibu) dan Implikasinya Terhadap Hurmatur Rada'ah, skripsi tidak diterbitkan, Yogyakarta: Universitas Islam Indonesia, 2010.

Agustinus H, Keluarga Sebagai Tempat Pembinaan Sumber Daya Manusia, Jakarta : Visindo Media Persada, 2007.

Alisriani, Winda, "Telaah terhadap Fatwa Yusuf al-Qardhawi tentang Bank Air Susu Ibu dan Konsekuensinya terhadap Larangan Perkawinan karena Sepersusuan, tesis tidak diterbitkan, Pekanbaru: UIN Sultan Syarif Kasim, 2015.

Ariani, Ibu Susui Aku. Bayi Sehat dan Cerdas dengan ASI, Bandung: Khasanah Intelektual, 2009.

Arisman, Buku Ajar Ilmu Gizi : Gizi dalam Daur Kehidupan, EGC. Jakarta, 2004.

Badan Pusat Statistik, BKKN, Departemen Kesehatan, Survey Demografi dan Kesehatan Indonesia 2006-2007. Jakarta: Badan Pusat Statistik, 2007.

Biancuzzo, Marie, Breastfeeding the Newborn: Clinical Strategies for Nurses, Michigan: Mosby, 1999.

Departemen Kesehatan RI, Buku Panduan Manajemen Laktasi, Jakarta: Direktorat Gizi Masyarakat, 1991.

Hooker, M.B., Islam Mazhab Indonesia: Fatwa-fatwa dan Perubahan Sosial, penerjemah: Iding Rasyidin Hasan, Jakarta: Teraju, 2003.

Ibnu Rusyd, Abu al-Walid, Bidayatul Mujtahid wa Nihayatul Muqtashid, Juz II, Mesir: Musthafa al-Babi, 1975.

Isti'anah, "Donor ASI (Air Susu Ibu) dan Implikasinya Terhadap Hubungan Kemahraman", Yogyakarta: Skripsi tidak diterbitkan, 2010), dalam http://digilib.Uin-suka.ac.id/17887/,

Lisa Marifah, "Tinjauan Hukum Islam Terhadap Jual Beli Air Susu Ibu (ASI)", Surabaya: Skripsi tidak diterbitkan, 2008. 
Majelis Ulama Indonesia, Himpunan Fatwa MUI, Jakarta: Erlangga, 2011.

Mataram, I. Komang Agusjaya, “Aspek Imunologi Air Susu Ibu”, Jurnal Ilmu Gizi, Vol. 2 No. 1, Februari 2011.

Nurmiati dan Besral, Pengaruh Durasi Pemberian ASI Terhadap KetahananHidup Bayi di Indonesia, Makara, Kesehatan, Vol. 12, No. 2, Desember 2008.

Roesli, U., Mengenal ASI Eksklusif, Jakarta: Trubus Agriwidya, 2005.

Sears, William, dkk., The Baby Book: Segala Hal yang Perlu Anda Ketahui tentang Bayi Anda Sejak Lahir Hingga Usia Dua Tahun, Jakarta: Serambi, 2007.

Soetjiningsih, ASI Petunjuk untuk Tenaga Kesehatan, Jakarta: EGC, 1997.

Wahjudi, Mencetak Generasi Cerdas Dan Berkualitas, Yogyakarta : Cempaka Putih , 2007.

Yudianto dkk., (ed.), Profil Kesehatan Indonesia Tahun 2014, Jakarta: Kementerian Kesehatan RI, 2015.

Yuliarti, Nurheti, Keajaiban ASI - Makanan Terbaik Untuk Kesehatan, Kecerdasan dan Kelincahan si Kecil, Yogyakarta: Penerbit ANDI, 2010.

\section{PerUndang-Undangan}

Undang-undang Dasar Republik Indonesia Tahun 1945

Undang-undang Nomor 36 Tahun 2009 Tentang Kesehatan

Keputusan Menteri Kesehatan RI Nomor 237/Menkes/SK/IV/1997 Tentang Pemasaran Pengganti ASI

Keputusan Menteri Kesehatan RI Nomor 459/Menkes/SK/IV/2004 Tentang Pemberian ASI secara Eksklusif pada bayi di Indonesia

Peraturan Menteri Kesehatan Nomor 240/Menkes/PER/V/1985 Tentang Pengganti ASI

Peraturan Pemerintah Nomor 33 Tahun 2012 Tentang Pemberian ASI Eksklusif 